\title{
HUBUNGAN ANTARA KEBIASAAN MEROKOK DENGAN KESEHATAN RONGGA ORAL PADA MASYARAKAT BENTANGAN WONOSARI KLATEN
}

\author{
Wiwin Winarni ${ }^{1}$, Agil Melina $^{2}$
}

\begin{abstract}
Background Smoking has been widespreads to all group of societies and becomes increased dramatically, especially children and teenager. This condition is caused by the rising of force of the mass media to advertise the cigarette products. The total number of smoker in Indonesia has been increased dramatically. Study conducted by Tobacco Atlas in 2009 showed that Indonesia got number five for the country with large smoker population all over the world.

Purpose to analyze the correlation between smoking and health of cavity oral of peoples in Bentangan Wonosari Klaten.

Methode This research used analytic with correlation design. The total respondens involved in this research were 40 peoples. Data was collected by using quessionaires and observing the oral cavity of the respondens using Oral Hygiene Index. The data was analyzed by using chi square statistic.

Result 1) Respondens with mild category is $32,5 \%$, moderate $20 \%$, severe $35 \%$ and very severe $12,5 \%$. 2) The total number of respondens who suffered from oral health disorder $27,5 \%$ and responden with healthy cavity oral $72,5 \%$. Conclusion The variable of smoking has related to peoples oral health condition in Bentangan Wonosari Klaten $(p=0,002)$
\end{abstract}

Keywords : smoking, health of oral cavity

\section{PENDAHULUAN}

Kebiasaan merokok sudah meluas di hampir semua masyarakat dan cenderung mengalami peningkatan terutama di kalangan anak-anak dan juga remaja. Di Indonesia jumlah perokok selalu mengalami peningkatan. Hal ini didukung oleh sejumlah produsen rokok yang memproduksi jenis rokok filter yang diakui oleh produsen sebagai rokok yang jauh lebih aman dari rokok non-filter. Ini sangat kontradiktif dengan negara-negara maju dimana jumlah perokok mengalami penurunan dari tahun ke tahun. Tobacco Atlas (2009) menunjukkan bahwa peringkat Indonesia pada tahun 2007 tetap pada posisinya yaitu peringkat ke lima. Dinkes Propinsi Jawa Tengah (2014) menyebutkan pada tahun 2020 diperkirakan bahwa tembakau akan menjadi penyebab utama kematian dan kecacatan yang dapat menewaskan lebih dari 10 juta orang setiap tahunnya. (Kholasoh, 2007) Menurut Kholasoh (2007), asap panas pembakaran rokok berhembus terus-menerus ke dalam rongga mulut dan merupakan rangsang panas yang menyebabkan perubahan aliran darah sehingga mengurangi pengeluaran air ludah. Akibatnya rongga mulut menjadi kering dan lebih anaerob (suasana bebas zat asam) sehingga memberikan dampak resiko gangguan kesehatan gigi lebih besar. Desa Karang Bentangan adalah salah satu desa di Kecamatan Wonosari Kabupaten Klaten. Hasil survey pendahuluan diperoleh data bahwa mayoritas 
penduduk mempunyai kebiasaan merokok dengan jenis rokok yang bervariasi. Banyak masalah yang ditimbulkan pada kesehatan rongga oral. Ada juga warga yang terbiasa merokok namun tidak mengalami gangguan kesehatan gigi. Berdasarkan uraian tersebut maka peneliti tertarik untuk melakukan penelitian tentang hubungan antara kebiasaan merokok dengan kesehatan rongga oral pada masyarakat di Desa Karang Bentangan Wonosari Klaten.

\section{TUJUAN PENELITIAN}

Penelitian ini bertujuan untuk menganalisis ada tidaknya hubungan antara kebiasaan merokok dengan kesehatan rongga oral pada masyarakat Bentangan Wonosari Klaten.

\section{METODE PENELITIAN}

Penelitian ini merupakan bentuk penelitian analitik dengan desain korelasi untuk mengetahui hubungan antara kebiasaan merokok sebagai variabel bebas dan kesehatan rongga oral sebagai variabel terikat.

\section{POPULASI, SAMPEL DAN TEKNIK SAMPLING}

Populasi pada penelitian ini adalah seluruh masyarakat Desa Karang Bentangan Wonosari Klaten yang mempunyai kebiasaan merokok. berjumlah 40 orang. Besar sampel yang peneliti ambil adalah 40 responden sesuai dengan kriteria yang ditetapkan oleh peneliti. Teknik sampling yang peneliti gunakan adalah sampling jenuh.

\section{HASIL PENELITIAN}

Berdasarkan penelitian yang telah dilakukan bulan April 2015 didapatkan hasil penelitian sebagai berikut :
Tabel 1

Distribusi Frekuensi

Kebiasaan Merokok

\begin{tabular}{ccc}
\hline $\begin{array}{c}\text { Kebiasaan } \\
\text { Merokok }\end{array}$ & $\mathrm{f}$ & $\%$ \\
\hline Ringan & 13 & 32,5 \\
\hline Sedang & 8 & 20 \\
\hline Berat & 14 & 35 \\
\hline Sangat berat & 5 & 12,5 \\
\hline Jumlah & 40 & 100 \\
\hline
\end{tabular}

Dari data di atas diperoleh informasi bahwa mayoritas responden mempunyai kebiasaan merokok berat sebanyak 14 responden dan paling sedikit responden dengan kebiasaan merokok sangat berat sebanyak 5 responden.

Tabel 2

Distribusi Frekuensi

Kesehatan Rongga Oral

\begin{tabular}{|c|c|c|}
\hline $\begin{array}{c}\text { Kesehatan } \\
\text { Rongga Oral }\end{array}$ & $f$ & $\%$ \\
\hline $\begin{array}{l}\text { Tidak ada } \\
\text { masalah }\end{array}$ & 11 & 27,5 \\
\hline Ada masalah & 29 & 72,5 \\
\hline Jumlah & 40 & 100 \\
\hline
\end{tabular}

Dari data di atas diperoleh informasi bahwa mayoritas responden yang mempunyai kebiasaan merokok mengalami masalah kesehatan rongga oral sebanyak 29 responden dan responden yang tidak mengalami masalah kesehatan oral sebanyak 11 orang.

Tabel 3

Hasil Analisis Chi Square antara

Kebiasaan Merokok dan Kesehatan Rongga Oral

\begin{tabular}{ccccccc}
\hline \multirow{2}{*}{$\begin{array}{c}\text { Kesehatan } \\
\text { rongga } \\
\text { oral }\end{array}$} & $\begin{array}{c}\text { Rin } \\
\text { gan }\end{array}$ & $\begin{array}{c}\text { Sed } \\
\text { ang }\end{array}$ & $\begin{array}{c}\text { Ber } \\
\text { at }\end{array}$ & $\begin{array}{c}\text { San } \\
\text { gat } \\
\text { ber } \\
\text { at }\end{array}$ & $\begin{array}{c}\text { Ju } \\
\text { la } \\
\mathrm{h}\end{array}$ & $p$ \\
\hline $\begin{array}{c}\text { Tidak ada } \\
\text { masalah }\end{array}$ & 8 & 3 & 0 & 0 & 11 & \\
\hline $\begin{array}{c}\text { Ada } \\
\text { masalah }\end{array}$ & 5 & 5 & 14 & 5 & 29 & 0,002 \\
\hline Jumlah & 13 & 8 & 14 & 5 & 40 & \\
\hline
\end{tabular}


Dari tabel 3 diperoleh informasi bahwa hasil uji chi square menunjukkan $p=0,002$. Karena nilai $\mathrm{p}<0,05$ maka dapat disimpulkan bahwa terdapat hubungan antara kebiasaan merokok dengan kesehatan rongga oral pada masyarakat Bentangan, Wonosari.

\section{PEMBAHASAN}

1. Gambaran kebiasaan merokok pada masyarakat Bentangan

Berdasarkan data yang didapatkan pada tabel 1, dari 40 responden didapatkan 32,5\% kategori ringan, 20\% kategori sedang, 35\% kategori perokok berat dan 12,5\% kategori sangat berat. Mayoritas responden masuk dalam kategori perokok berat yaitu merokok sekitar 21-30 batang sehari. Kholasoh (2007) menjelaskan seseorang dapat menjadi seorang perokok karena adanya beberapa tahapan. Tahapan tersebut dimulai dari persiapan, inisiasi, menjadi perokok hingga akhirnya menjadi perokok tetap. Seseorang dapat menjadi perokok tetap saat faktor psikologis dan proses biologis bergabung sehingga semakin mendorong perilaku untuk merokok hingga akhirnya menjadi seorang perokok tetap. Caldwell (2009) menyebutkan beberapa hal yang menjadi alasan seseorang mempunyai kebiasaan merokok antara lain rokok dapat membuat seseorang menjadi lebih santai, membantu berpikir, rokok dapat menjadi teman saat sendirian, membantu melewatkan waktu, dan mampu membangkitkan semangat. Alasan-alasan tersebut diatas juga dijumpai pada masyarakat Desa Bentangan sehingga warga sulit meninggalkan kebiasaan merokok.
2. Gambaran masalah kesehatan rongga oral

Berdasarkan data pada tabel 2 didapatkan $72,5 \%$ responden mempunyai masalah kesehatan oral dan $27,5 \%$ tidak mempunyai masalah kesehatan rongga oral. Masalah kesehatan rongga oral yang ditemukan pada warga antara lain adalah karies gigi, gigi kuning, plak gigi, dan hiperpigmentasi pada gusi. Margareta (2012) menjelaskan bahwa perubahan warna menjadi kuning dapat disebabkan karena pengaruh dari rokok. Asap rokok dapat menyebabkan stimulasi produksi melanin pada rongga mulut (Regezi, Sciubba dan Jordan, 2004) Masalah kesehatan lain yang dapat muncul akibat merokok antara lain penyakit periodontal seperti gingivitis dan periodontitis. (Muttaqin dan Sari, 2011)

3. Hubungan kebiasaan merokok dengan kesehatan rongga oral Jaya (2009) menjelaskan rokok merupakan gabungan bahanbahan kimia. Satu batang rokok yang dibakar akan mengeluarkan 4000 bahan kimia. Rokok menghasilkan suatu pembakaran yang tidak sempurna yang dapat diendapkan dalam tubuh ketika dihisap. Secara umum komponen rokok dibagi menjadi dua golongan besar yaitu komponen gas $(92 \%)$ dan komponen padat atau partikel (8\%).

Komponen gas asap rokok terdiri dari karbonmonoksida, karbondioksida, hidrogen sianida, amoniak, oksida dari nitrogen dan senyawa hidrokarbon. Partikel rokok terdiri dari tar, nikotin, benzantracne, benzopiren, fenol, cadmium, indol, karbazol dan krezol. Zatzat ini beracun, mengiritasi dan menimbulkan kanker (karsinogen). Nikotin merupakan 
komponen yang paling banyak dijumpai di dalam rokok.

Tar, nikotin dan karbonmonoksida merupakan tiga macam bahan kimia yang paling banyak berbahaya dalam asap rokok. Tar adalah kumpulan dari beribu-ribu bahan kimia dalam komponen padat adap rokok dan bersifat karsinogenik. Pada saat rokok dihisap, tar masuk ke rongga mulut sebagai uap padat yang setelah dingin akan menjadi padat dan membentuk endapan berwarna coklat pada permukaan gigi, saluran napas dan paru-paru. Komponen tar mengandung radikal bebas yang berhubungan dengan risiko timbulnya kanker. Nikotin merupakan bahan yang bersifat toksik dan dapat menimbulkan ketergantungan psikis. Nikotin merupakan alkaloid alam yang bersifat toksik, berbentuk cairan, tidak berwarna dan mudah menguap. Zat ini dapat berubah warna menjadi coklat dan berbau seperti tembakau jika bersentuhan dengan udara. Nikotin berperan dalam menghambat perlekatan dan pertumbuhan sel fibroblast ligamen periodontal menurunkan isi protein fibroblast serta dapat merusak sel membran.

Berdasarkan hasil analisa chi square menunjukkan nilai $p=0,002$ sehingga dapat disimpulkan bahwa terdapat hubungan antara kebiasaan merokok dengan kesehatan rongga oral. Hal ini sesuai dengan pendapat Jaya (2009) bahwa efek merokok yang timbul dipengaruhi oleh banyaknya jumlah rokok yang dihisap, lamanya merokok, jenis rokok yang dihisap bahkan berhubungan dengan dalamnya hisapan rokok yang dilakukan.

Gluca et.,al (2014) menjelaskan merokok dapat menyebabkan perubahan penting pada saliva karena saliva merupakan cairan tubuh pertama yang berkontak langsung dengan gas yang dihasilkan rokok. Penggunaan tembakau menyebabkan stimulasi cairan saliva dan penurunan enzim. Rokok menyebabkan penurunan tingkat $\lg A$, IgG dan $\lg M$ pada saliva perokok.

Komponen dari rokok menciptakan lapisan tebal berupa plak bakteri, yang tampaknya sulit dihilangkan oleh pasien dan menyebabkan inflamasi kronis pada jaringan ginggival. Rokok dapat mengubah imunoregulasi sel $T$ dan diferensiasi sel $B$ menyebabkan penurunan produksi lgs yang melindungi mukosa oral untuk melawan bakteri periodontal. Nilai Igs dalam saliva yang rendah dapat menjadi faktor resiko terjadinya penyakit oral khususnya periodontal.

Pada kondisi perioditis, tubuh bereaksi dengan memproduksi antibodi melawan mikroorganisme yang menyebabkan infeksi. Akan tetapi, pada perokok terdapat penurunan jumlah limposit $\mathrm{T}$ helper yang berguna dalam fungsi limfosit $B$ dan untuk memproduksi antibodi, akibatnya penurunan tingkat antibodi.

Penurunan nilai $\lg \mathrm{A}$ pada saliva dihubungkan dengan peningkatan derajat inflamasi ginggiva. $\mathrm{Hal}$ tersebut memungkinkan terjadinya penurunan fungsi fibroblas ginggiva, perubahan neutrofil dan perubahan serum antibodi melawan mikroorganisme patogen. Penurunan tingkat imunoglobulin berhubungan dengan proses perkembangan lesi periodontal. 
KESIMPULAN DAN SARAN

1. Kesimpulan

Berdasarkan pembahasan yang diuraikan dapat disimpulkan bahwa terdapat hubungan antara kebiasaan merokok dan kesehatan rongga oral pada Masyarakat Bentangan Wonosari Klaten.

2. Saran

a. Pemeriksaan histopatologi perlu dilakukan untuk mendapatkan pengamatan secara mikroskopis sehingga dapat meminimalkan subyektivitas hasil observasi.

b. Perlu dilakukan pemeriksaan imunologi pada rongga oral untuk mengidentifikasi respon imunologi terhadap kandungan rokok.

c. Perlu dilakukan studi lanjut mengenai faktor lain yang dapat mempengaruhi kesehatan rongga oral.

\section{DAFTAR PUSTAKA}

Caldwell, Ernest. 2009. Berhenti Merokok. Pustaka Populer, Yogyakarta.

Diyono dan Sri Mulyanti. 2013. Buku Ajar Keperawatan Medikal Bedah: Sistem Pencernaan (Dilengkapi Contoh Studi Kasus dengan Aplikasi NNN (Nanda NOC NIC)). Kencana, Jakarta.

Gluca, et al. 2014. "Levels of Salivary Immunoglobulins and Periodontal Evaluation in Smoking Patients". BMC Imunologi.

Hidayat, Aziz Alimul. 2009. Metodologi Penelitian Keperawatan dan Teknik Analisis Data. Salemba Medika, Jakarta.
2008. Riset Keperawatan dan Teknik Penulisan IImiah. Salemba Medika, Jakarta.

Jaya, Muhammad. 2009. Pembunuh Berbahaya Itu Namanya Rokok. Riz'ma, Yogyakarta.

Kaul Melinder dan Wilda Hafny Lubis. 2013. "Hubungan Kebiasaan Merokok dengan terjadiya coated tongue pada Pegawai Non Akademik Universitas Sumatera Utara". Densitry e-journal vol. 2 no. 1 2013.

Kholasoh, Siti. 2007. Terima Kasih Untuk Rokokmu. Mediatama, Surakarta.

Muttaqin, Arif dan Kumala Sari. $2011 . \quad$ Gangguan Gastrointestinal: Aplikasi Asuhan Keperawatan Medikal Bedah. Salemba Medika, Jakarta.

Margareta, Shinta. 2012. 101 Tips \& Terapi Alami agar Gigi Putih \& Sehat. Pustaka Cerdas, Yogyakarta.

Proverawati, Atikah dan Eni Rahmawati. 2012. Perilaku Hidup Bersih dan Sehat (PHBS). Nuha Medika, Yogyakarta.

Regezi, Joseph A, James J. Sciubba dan Richart C.K Jordan. 2004. "Oral Pathology Clinical Pathologic Correlation". USA: Library of Congress Cataloging Publication Data.

Riwidikdo, Handoko. Statistik Kesehatan Dengan Aplikasi SPSS dalam Prosedur Penelitian. Yogyakarta: Rohima Press, 2013. 
Suyanto. 2011. Metodologi dan Aplikasi Penelitian Keperawatan. Nuha Medika, Yogyakarta.

Trim, Bambang. 2006. Merokok Itu Konyol. Jakarta: Ganeca Exact, 2006.

1 Dosen AKPER Panti Kosala Surakarta

2 Mahasiswa AKPER Panti Kosala Surakarta 